\section{An assessment of climate change impacts on the tropical forests of Central America using the Holdridge Life Zone (HLZ) land classification system}

\author{
Kaysara Khatun ${ }^{(1)}$, Pablo Imbach ${ }^{(2)}$, Juan Carlos Zamora ${ }^{(2)}$
}

Ecological models have predicted shifts in forest biomes, yet there have been very few studies that have looked at the implications on carbon stocks due to these shifts. Carbon is closely correlated to biomass and constitutes an important characteristic of the forest ecosystem. It has implications for conservation and land use practices, especially for climate change mitigation strategies currently under discussion, such as the Reduced Emissions from Deforestation and Forest Degradation (REDD). This study couples the Holdridge Life Zone (HLZ) classification with the ECHAM5 model, to evaluate the impacts of climate change using the Special Report on Emissions Scenarios (SRES) A2, A1B and B1 for the Central American region. We utilize methodologies which combine biophysical variables with model output to assess the impacts on carbon stocks for two time periods, 2000 and 2100. Results show that overall the tropical category of the HLZ classification gains area as a consequence of one type of HLZ shifting to another forest type. In many cases the shifts lead to some categories of HLZ being lost in their entirety. Elevation-associated life zones are particularly vulnerable to future climatic changes. A strong point of our approach is that differences between disaggregate regional and aggregate country levels can be compared. We suggest that a critical focus of conservation and management efforts should be concentrated on where vulnerable biomes are at most risk, i.e., biomes that shift and/or reduce fall under the vulnerable category.

Keywords: Climate Change, Conservation, Forests, Holdridge Life Zones

\section{Introduction}

The destruction of the world's forests, mainly in the tropics, releases about two billion tonnes of carbon per year. Thus, tropical deforestation accounts for about $25 \%$ of anthropogenic emissions of carbon dioxide $\left(\mathrm{CO}_{2}\right)$ and $12 \%$ of total greenhouse gases (GHG). Recent figures by the FAO (2010) show that there are signs that deforestation numbers are decreasing in several countries, but nonetheless continue to grow at an alarmingly high rate in others. Climate change, in turn, is predicted to have farreaching impacts on global forests with most ecosystems and landscapes impacted through changes in species composition, productivity and biodiversity (Scholze et al. 2006, Sitch et al. 2003).

The Convention on Biological Diversity (2007) highlights that although ecosystems have adapted to changing conditions in the past, current changes are occurring at rates not seen historically, therefore, reductions in GHG can lessen these pressures, and give these systems time to adapt. Tropical forests not only contribute significantly to emissions through deforestation, but can also provide opportunities to lower $\mathrm{CO}_{2}$ levels by reducing the amounts from the atmosphere through a process referred to as the carbon

$\square$ (1) Institute of Environmental Science and Technology (ICTA), Universitat Autònoma de Barcelona, 08193 Bellaterra (Spain); (2) Programa de Cambio Climático - CATIE, 30501 Turrialba (Costa Rica)

@ Kaysara Khatun (kaysara1@googlemail.com)

Received: Aug 21, 2012 - Accepted: Mar 01, 2013

Citation: Khatun K, Imbach P, Zamora JC, 2013. The implications of climate change impacts on conservation strategies for central America using the Holdridge Life Zone (HLZ) land classification. iForest 6: 183-189 [online 2013-05-08] URL: http://www.sisef.it/iforest/ contents/?id=ifor0743-006

Communicated by: Roberto Tognetti

cycle, driven by respiration and photosynthesis (Khatun et al. 2010). In this study, we evaluate carbon stocks for the different forest types in Central America, broadly falling into sub-categories of dry, moist, wet and rain forests based on the Holdridge Life Zone (HLZ) system of classification. The HLZ classification provides a basis for defining local ecosystems in a globally comparable framework. The HLZ classification is coupled with projections from the ECHAM5, a comprehensive general circulation model (GCM), developed by the Max Planck Institute to incorporate the impacts of climate change under the Intergovernmental Panel on Climate Change (IPCC) Special Report on Emissions Scenarios (SRES) A2, A1B and B1 (IPCC 2000). These consist of explorative scenario's that are given numbers $\mathrm{A} 1, \mathrm{~A} 2, \mathrm{~B} 1$ and $\mathrm{B} 2$, because of the difficulty to adequately capture the multifaceted nature of the scenarios by a short name (Munasinghe \& Swart 1999). The starting point for each projection was a narrative or "storyline", describing the way world population, economies and political structure may evolve over the next few decades. There are a number of studies that have used the HLZ classification system together with climate models; two based in Africa have looked at the impacts of climate change on global forest resources. The first by Dixon et al. (1996) is based in Cameroon and Ghana. The authors conclude that the areal distribution of West African forests is likely to shift resulting in subsequent loss of forests. The second study by Matarira \& Mwamuka (1996) reaches the same conclusion for Zimbabwe; the two studies differ in their selection of GCM applied, these are the Geophysical Fluid Dynamics (GFDL) Model (Manabe \& Wetherald 1987), and the Goddard Institute of Space Studies (GISS) model (Hansen et al. 1983), respectively. Other studies that have utilized the HLZ vegetation classification system, as a result of its simplicity as well as general accuracy, are by Post et al. (1982) and Smith et al. (1992) on carbon flux, whilst a number have focused on the structure and ecological characteristics of forests in various regions (Shugart 1998, Lugo et al. 1999). The former describes key ecological concepts, including vegetation/ climate relationships, landscape ecology and ecological modeling. A variety of ecological models are presented, and their applications in predicting responses to natural change. The latter study develops a map of the life zones for the United States, based on the HLZ system, as a tool for ecosystem mapping, and compares the map with other global vegetation classification and mapping efforts. A recent study using the HLZ classification system is by Enquist (2002), where the mean annual precipitation and tempera- 
ture ranges are varied to reflect different magnitudes of climate change using spatial models generated in a Geographical Information System (GIS), and thus used to predict the distributions of nineteen forest types in Costa Rica. The author observes forest shifts and finds four out of the nineteen HLZ zones for the country to be particularly susceptible to climate change. Chen et al. (2003) also use the HLZ to study the possible response of life zones in China under doubled atmospheric $\mathrm{CO}_{2}$ concentration. They conclude that the latitudinal distribution of HLZ would become irregular due to climate change. The only study in Central America on carbon stocks is an economic assessment by Khatun (2011), but does not use projections under climate change.

The objective of this study is to evaluate the impact on the areal distribution of the HLZ of tropical forest, and subsequently the carbon stocks in Central America in the present characterized by a baseline year (2000) and compare it with a future projected year (2100). Forest biomass, expressed in terms of dry weight of living organisms, is an important measure for analyzing ecosys tem productivity and also for assessing energy potential and the role of forests in the carbon cycle. Carbon is closely correlated to and calculated directly from biomass and constitutes an important characteristic of the forest ecosystem (FAO 2010). It features heavily in mitigation strategies currently under discussion such as reducing emissions under forest deforestation and degradation, referred to as REDD. Carbon storage is also the non-timber value most often included in forest accounts and can be equated directly with timber available in terms of biomass content (Khatun 2011). In this study the area change of the HLZ is the model output, and carbon content derived from the biomass for each HLZ, which is then overlaid after the area change has been obtained - it is assigned as a demonstrative indicator of the implications for conservation, such as those under REDD. We make no assumption that the adopted approach automatically conveys a shift of the corresponding forest ecosystems with their typical average carbon stock.

Overall, Central America lost $19 \%$ of its forest between 1990 and 2005; in 1999, the rate of loss was estimated at about $2 \%$ annually in recent decades, among the highest of any region in the world (FAO 1999). However, consistent with global trends, the deforestation rates are slowing. The drivers of deforestation in Central America are mainly due to timber extraction and land use change. Increasing income and population will continue to result in greater demands being placed on forest resources. Moreover, these same pressures will also increase the demands placed on forests for the other services they provide for the conversion of forests to alternative land uses to meet the escalating demands for food, water and fiber (FAO 2011). On top of the stresses highlighted above, impacts from climate change in Central America are expected to be considerable. Based on the analysis of simulations from 21 GCMs showing temperature and precipitation changes over Central and South America. The IPCC Fourth Assessment Report summarizes the following for Central America: "All of Central and South America is very likely to warm during this century. The annual mean warming is likely to be larger than the global mean warming. Annual precipitation is likely to decrease in most of Central America, with the relatively dry boreal spring becoming drier. [...]" (IPCC 2007).

Therefore, there is clear merit in assessing the impacts of climate change on the different forest types in Central America. The areal distribution by forests type using the HLZ classification is assessed under three climate change scenarios A2, A1B and B1 and subsequently the significance for conservation options, and implications for land use planning more generally. This study can be of interest to stakeholders, in the land use sector (based on the type of land available for the nature of the land use), provide guidance to policymakers on conservation and mitigation strategies (i.e., in the case for REDD) in terms of the impacts of climate change on the tropical forest, at a regional scale and by forest types, as well as to economists wishing to assess ecosystem services provided by tropical forests, i.e., carbon, biomass and in many cases timber can be

Tab. 1 - The Holdridge Life Zones associated with tropical forest biomes and their corresponding biomass. Source: Tosi (1996).

\begin{tabular}{clc}
\hline Code & Holdridge life zone & $\begin{array}{c}\text { Biomass } \\
\text { (ton ha }\end{array}$ \\
\hline 411 & Tropical very dry forest & 148 \\
421 & Premontane dry forest & 186 \\
431 & Lower montane dry & 137 \\
& forest & \\
441 & Montane moist forest & 110 \\
451 & Sub-alpine paramo & 20 \\
511 & Tropical dry forest & 268 \\
521 & Premontane moist forest & 326 \\
531 & Lower montane moist & 226 \\
& forest & 124 \\
541 & Montane wet forest & 20 \\
551 & Sub-alpine rain paramo & 449 \\
611 & Tropical moist forest & 354 \\
621 & Premontane wet forest & 228 \\
631 & Lower montane wet & \\
& forest \\
641 & Montane rain forest & 86 \\
711 & Tropical wet forest & 474 \\
721 & Premontane rain forest & 242 \\
731 & Lower montane rain & 150 \\
& forest \\
\hline
\end{tabular}

calculated from biomass (see Husch et al. 2003, Khatun 2011).

\section{Geographical location of study}

Our study is located in the region of Central America, based on the physical definition which consists of seven countries: Belize, Costa Rica, El Salvador, Guatemala, Honduras, Nicaragua and Panama. Central America is a topographically complex region divided in the Pacific and Caribbean watersheds by a cordillera that runs from south to north, sometimes reaching 4000 meters above sea level. The climate is tropical with a relatively small range in mean monthly temperatures across the year (compared to temperate zones). Precipitation has a bimodal pattern in that it divides the year in dry (from November to April) and wet seasons that are more pronounced in the Pacific watersheds, while the Atlantic side has yearround rains. Annual precipitation is highly variable (Magaña et al. 1999) and has also a decreasing north-south gradient. Evergreen forests cover pristine areas in the Atlantic watersheds and shift to drier savannahs in the northern countries and Pacific watersheds. In 2003, natural vegetation, including secondary forests and selectively logged forests, was estimated to cover $57 \%$ of Mesoamerica, of which $23 \%$ is primary forests (FAO 2010). The remaining area was used mostly for crop and cattle production $(42 \%)$ with $1-2 \%$ in urban and other land covers (DeClerck et al. 2010).

\section{Methodology}

The statistical information, including biomass, forest type, area, etc. are from a variety of sources: Centro Agronómico Tropical de Investigación y Enseñanza (CATIE), plus a number of Institutes including Food and Agricultural Organization (FAO), World Resource Institute (WRI), and the World Bank. The core variables remain the biomass (Tosi 1996) and the forest area, obtained from modeling the HLZ with ECHAM 5. Tab. 1 presents the tropical forest type or HLZ used in this study for Central America and their corresponding biomass.

\section{The model and the HLZ classification}

The HLZ classification system is an empirically based system that characterizes vegetation types of terrestrial ecosystems in equilibrium with its climate. The system can be visualized in a triangular coordinate system filled with hexagons that are formed by the intersection of three parameters: mean annual bio-temperature, annual precipitation and a potential evapotranspiration ratio, the latter being calculated using the first two parameters. The biotemperature estimates the average temperature where vegetation grows (between 0 and $30^{\circ} \mathrm{C}$ - Holdridge 1947 , 1967). 
To map the baseline life zones (those under current climate conditions) we used the high-resolution WorldClim dataset, version 1.4 (Hijmans et al. 2005) that provides monthly average of precipitation and temperature for the $\sim 1950-2000$ period at high resolution $\left(1 \mathrm{~km}^{2}\right.$ pixel size $)$. Life zones scenarios under future average-climate conditions were calculated using 10 realizations from the ECHAM5-GCM under low (3), medium (4) and high (3) emission scenarios (B1, $\mathrm{A} 1 \mathrm{~B}$ and $\mathrm{A} 2$, respectively) from the IPCC-SRES (IPCC 2000) for the 2070-2099 period. The model is selected based on Conde et al. (2011), which includes a ranking of all global GCM based on regional (for Mexico) and global performance to simulate current climate conditions and spatial resolution.

Evaluating the carbon baseline and potential of the Central American forests

The estimates of carbon in the forests are based on the UNFCCC definitions (IPCC 2000) which identifies five carbon pools biomass for above ground (tree density, AB), biomass for below ground (roots, BG), litter (leaves, Li), dead wood (fallen trees and branches, DW) and soil (So). In this study we use above and below ground biomass to calculate carbon. The biomass can be converted to carbon content $\left(C_{\text {cont }}\right)$ by taking half of the biomass $(B)$ weight (the IPCC default value - eqn. 1):

$$
C_{\text {cont }}=B \cdot 0.5
$$

where both $C_{\text {cont }}$ and $B$ are expressed in $\mathrm{Mg}$ $\mathrm{ha}^{-1}$. The root biomass is typically estimated to be $20 \%$ of the aboveground forest carbon stocks (Gibbs et al. 2007).

The basic approach in the IPCC Guidelines for emissions and removals estimate that Emission/removal $=$ total area data $\cdot$ carbon stock changes / hectare. Carbon storage is based on calculating the difference or net in carbon stocks between a project and its baseline and a given point in time in the future. This method is referred to as the stock change method (IPCC 2000). A positive net value determines the number of carbon credits that can be claimed in terms of monetary gain for a project. Here it is given by eqn. 2 :

$$
C_{\text {proj }}=0.5 B \cdot A_{(A 2, A l B, B I)}-0.5 B \cdot A_{\text {baseline }}
$$

where $C_{\text {proj }}$ are the carbon projections $(\mathrm{Mg}$ $\left.\mathrm{ha}^{-1}\right), B$ is the biomass $\left(\mathrm{Mg} \mathrm{ha}^{-1}\right), A_{(\mathrm{A} 2, \mathrm{AlB}, \mathrm{B} 1)}$ are the areas projected for $\mathrm{A} 2, \mathrm{~A} 1 \mathrm{~B}$, and $\mathrm{B} 1$, respectively $\left(\mathrm{ha}^{-1}\right)$, and $A_{\text {baseline }}$ is the area for the baseline $\left(\mathrm{ha}^{-1}\right)$. The main assumption made for this study is that we use the potential forested areas and not the actual forested areas for the Central American region, in that the model is based on current and projected outputs in the absence of human inter-

\begin{tabular}{|c|c|c|c|c|c|c|c|c|}
\hline $\begin{array}{l}\text { Holdridge Zones } \\
\text { (Only tropical HLZ) }\end{array}$ & $\frac{\mathbb{N}}{\bar{D}}$ & 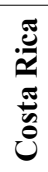 & 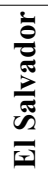 & 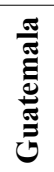 & 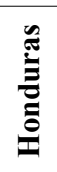 & 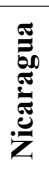 & 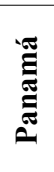 & $\begin{array}{l}\text { Total } \\
\text { HLZ }\end{array}$ \\
\hline Number of HLZ (baseline) & 5 & 11 & 7 & 14 & 10 & 9 & 7 & 63 \\
\hline Number of HLZ (A2) & 4 & 9 & 5 & 12 & 8 & 6 & 7 & 51 \\
\hline Number of HLZ (A1B) & 4 & 9 & 5 & 13 & 8 & 6 & 7 & 52 \\
\hline Number of HLZ (B1) & 4 & 9 & 5 & 13 & 8 & 6 & 6 & 51 \\
\hline
\end{tabular}

Tab. 2 - The HLZ under the three SRES scenarios.

vention. This is carried out with the purpose of observing forest behavior for two time periods. This assumption protects us from the uncertainties of future land use, agriculture, grazing, etc., over a hundred years for the region. Modeling all aspects of land use, particularly for both agriculture and forestry simultaneously would be desirable; however, such a framework is beyond the scope and capacity of this study.

\section{Results and discussion}

Tab. 2 shows that under the three scenarios we have lost the total number of HLZ from the baseline case. From this we can infer that under climate change we can expect to observe more topographic homogeneity on a country level under all scenarios. We can see the distribution of these zones in comparison to the baseline in Fig. 1a-d.

Fig. 2 visualizes the results obtained from the outputs of the ECHAM5 model; it displays the area change under the three climate change scenarios $\mathrm{A} 2, \mathrm{~A} 1 \mathrm{~B}$, and $\mathrm{B} 1$ from the baseline.

The areal gains are occurring in the tropical variety of the HLZ classification of forest types, in moist, wet, rain, dry and very dry categories. A notable exception is Belize, where most of the HLZ forests appear to be shifting towards premontane moist forest. The biomass and thus the carbon stock for each of these forest types are different.

Tab. 3 shows the percentage difference from the baseline for carbon gains and losses under the HLZ classification for Central America for each of the IPCC scenarios. The distribution of the zones is noteworthy, in that they are uneven. In Belize, all the shifts are towards premontane moist forest, in El Salvador to tropical moist, in Guatemala to tropical wet, in Nicaragua and Honduras to tropical very dry and in Panama to tropical wet. Costa Rica is the only country that shows a little more distribution across the forests types. Across scales the results tell a different story, HLZ scale as can be seen from the country (average) numbers in Tab. 3 . The percentages here represent the aggregated values for the whole country under the IPCC scenarios and are therefore on a much larger scale. Bigger gains are shown under B1 and where there are losses, these are smaller under the same scenario.
From our analyses it can be seen that a gain in dry forest at the zone level is typical under A2, and gains in wetter biomes show up under B1. Most of the countries here follow similar trends with the anomalies being Belize, Costa Rica and Panama. The former set shows the biggest gain to be in premontane moist forest, and apart from a small gain in the tropical moist forest category, the other HLZ, including tropical dry and wet forests, experience severe losses. Costa Rica is less of a variance, as all forest types in the tropical HLZ category gain, the exception being tropical dry forest experiencing a small loss of $7 \%$ under $\mathrm{B} 1$. The premontane rain forest also gains in Costa Rica. In Panama, tropical dry forest shows a loss under all climate change scenarios. At a country scale, the results are in line with the assumption that under B1, the less emission intensive scenario should show the most positive outcomes. However, as we have seen from the HLZ forest types in each country, the story is more complex. We may be gaining overall in carbon stock but at the expense of the loss of entire forest biomes, which are shifting to other types. Aside from the tropical HLZ, the other categories of forest type are all shown to be vulnerable to the impacts of climate change, the distribution among these are fairly even; one zone does not stand out to be significantly more vulnerable over another.

For carbon the biomass of the forest is paramount, and according to Murphy \& Lugo (1986) the biomass is at a maximum on moist, rather than dry or very wet sites. Our results corroborate and show that drier forests in the tropical zones contain less biomass compared to moist and wet forests at the same elevation. Honduras and Nicaragua are nations that will lose virtually their entire forest area which will shift to the drier variety, experiencing a net loss, and zero benefits at a country level. All nations experience a more homogeneous landscape due to the reduction in the number of HLZ.

The results indicate that the effect of elevation-influenced temperature change is important for the maintenance of vegetation, consistent with findings by Enquist (2002) for the HLZ in Costa Rica. We have shown that ecological models predict climate change will shift the geographic distribution of tree 


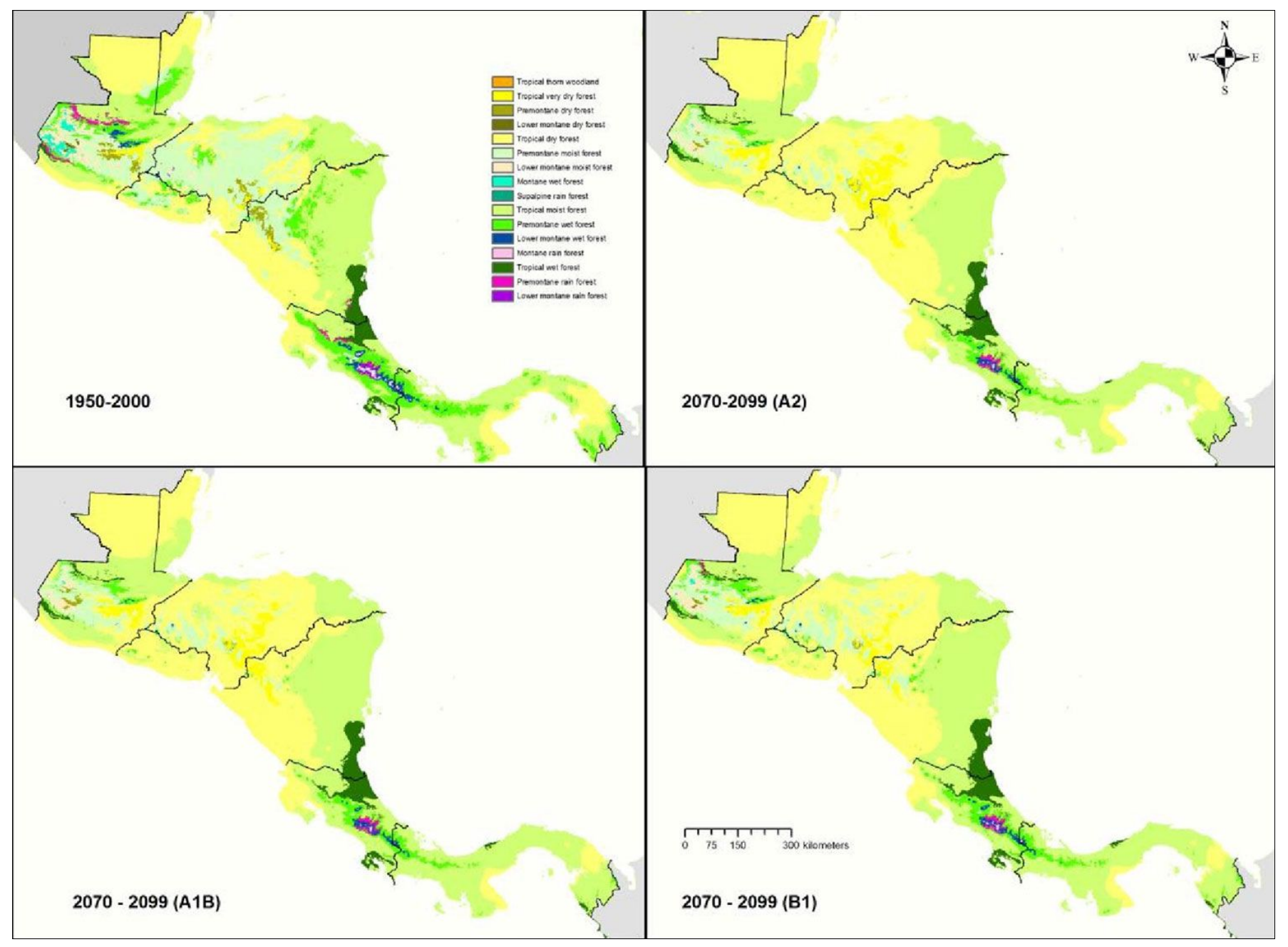

Fig. 1 - The distribution of the Holdridge Life Zones under the three IPCC scenarios A2, A1B, and B1 in comparison to the baseline.

\section{Forest Area (ha)}

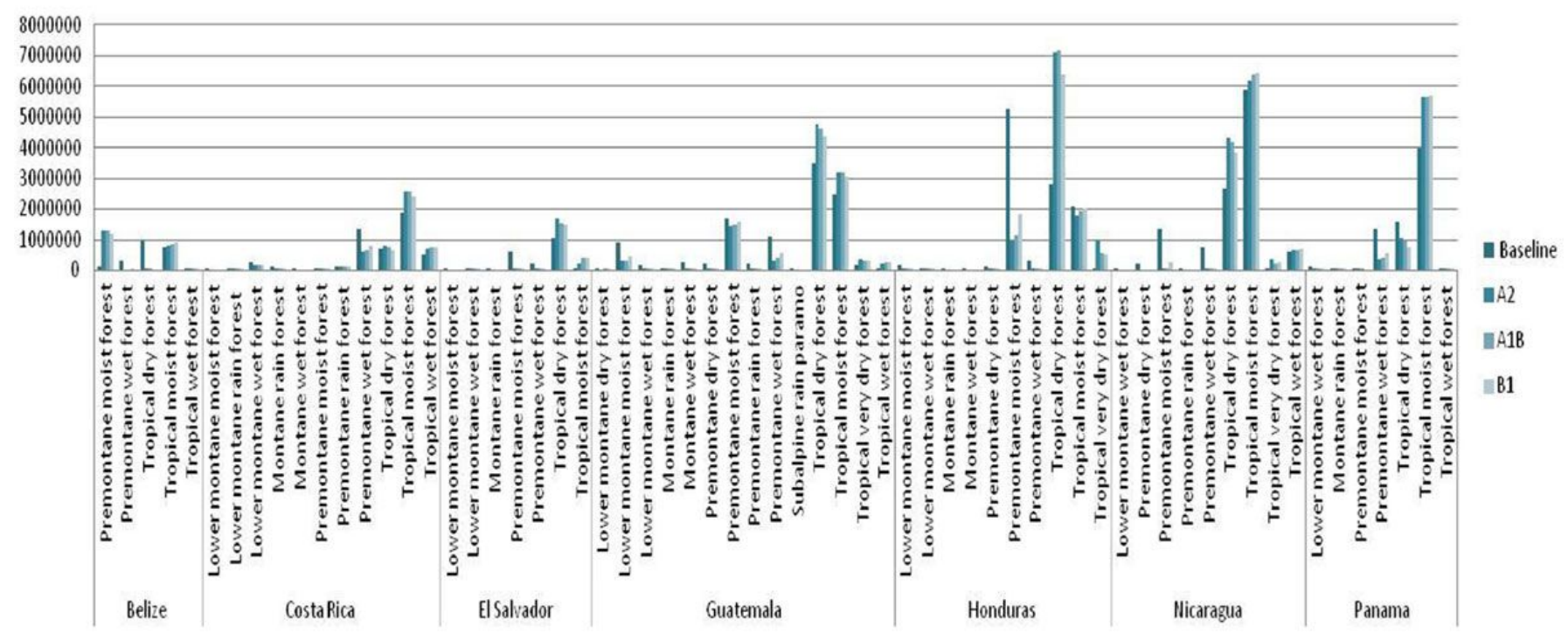

Fig. 2 - Forest area change under the IPCC scenarios for the HLZ forest types. 
Tab. 3 - Results from the climate change model ECHAM 5 for the percentage difference from the baseline.

\begin{tabular}{|c|c|c|c|c|c|c|c|c|c|}
\hline Country & $\mathbf{H Z}$ & $\begin{array}{c}\text { A2 } \\
\text { (\%) }\end{array}$ & $\begin{array}{c}\text { A1B } \\
(\%)\end{array}$ & $\begin{array}{l}\text { B1 } \\
(\%)\end{array}$ & Country & HZ & $\begin{array}{c}\text { A2 } \\
\text { (\%) }\end{array}$ & $\begin{array}{l}\text { A1B } \\
(\%)\end{array}$ & $\begin{array}{l}\text { B1 } \\
\text { (\%) }\end{array}$ \\
\hline \multirow[t]{6}{*}{ Belize } & Tropical dry forest & -99 & -100 & -100 & Guatemala & Premontane wet forest & -70 & -63 & -47 \\
\hline & Premontane moist forest & 1000 & 990 & 926 & (cont. $)$ & Lower montane wet forest & -94 & -91 & -77 \\
\hline & Tropical moist forest & 10 & 12 & 22 & & Montane rain forest & -93 & -87 & -80 \\
\hline & Premontane wet forest & -100 & -100 & -98 & & Tropical wet forest & 321 & 369 & 337 \\
\hline & Tropical wet forest & -75 & -52 & -60 & & Premontane rain forest & -100 & -98 & -86 \\
\hline & Country & 8 & 8 & 9 & & Country & 5 & 6 & 5 \\
\hline \multirow[t]{12}{*}{ Costa Rica } & Tropical dry forest & 16 & 6 & -7 & Honduras & Tropical very dry forest & 1017 & 580 & 533 \\
\hline & Premontane moist forest & -84 & -86 & -86 & & Premontane dry forest & -83 & -89 & -69 \\
\hline & Lower montane moist forest & -100 & -100 & -100 & & Tropical dry forest & 155 & 156 & 128 \\
\hline & Montane wet forest & -100 & -100 & -100 & & Premontane moist forest & -82 & -78 & -65 \\
\hline & Tropical moist forest & 38 & 37 & 30 & & Lower montane moist forest & -100 & -100 & -99 \\
\hline & Premontane wet forest & -54 & -52 & -39 & & Montane wet forest & -100 & -100 & -100 \\
\hline & Lower montane wet forest & -39 & -36 & -26 & & Tropical moist forest & -14 & -6 & -4 \\
\hline & Montane rain forest & -84 & -82 & -68 & & Premontane wet forest & -94 & -89 & -85 \\
\hline & Tropical wet forest & 43 & 51 & 49 & & Lower montane wet forest & -76 & -70 & -35 \\
\hline & Premontane rain forest & 21 & 26 & 17 & & Montane rain forest & -100 & -100 & -100 \\
\hline & Lower montane rain forest & -99 & -95 & -70 & & Country & -12 & -9 & -8 \\
\hline & Country & 8 & 8 & 7 & Nicaragua & Tropical very dry forest & 561 & 360 & 448 \\
\hline \multirow[t]{8}{*}{ El Salvador } & Tropical dry forest & 62 & 46 & 41 & & Premontane dry forest & -100 & -100 & -100 \\
\hline & Premontane moist forest & -98 & -98 & -95 & & Tropical dry forest & 65 & 59 & 45 \\
\hline & Lower montane moist forest & -100 & -100 & -100 & & Premontane moist forest & -96 & -94 & -79 \\
\hline & Tropical moist forest & 182 & 365 & 373 & & Tropical moist forest & 5 & 8 & 9 \\
\hline & Premontane wet forest & -90 & -85 & -70 & & Premontane wet forest & -98 & -95 & -89 \\
\hline & Lower montane wet forest & -98 & -98 & -80 & & Lower montane wet forest & -100 & -100 & -100 \\
\hline & Montane rain forest & -100 & -100 & -100 & & Tropical wet forest & 7 & 11 & 14 \\
\hline & Country & -3 & 1 & 2 & & Premontane rain forest & -100 & -100 & -100 \\
\hline \multirow[t]{9}{*}{ Guatemala } & Tropical very dry forest & 154 & 122 & 115 & & Country & -2 & 0 & 0 \\
\hline & Premontane dry forest & -62 & -81 & -84 & Panama & Tropical dry forest & -35 & -40 & -53 \\
\hline & Lower montane dry forest & -100 & -98 & -79 & & Premontane moist forest & -99 & -100 & -100 \\
\hline & Tropical dry forest & 38 & 34 & 26 & & Tropical moist forest & 41 & 42 & 42 \\
\hline & Premontane moist forest & -14 & -11 & -6 & & Premontane wet forest & -72 & -70 & -58 \\
\hline & Lower montane moist forest & -67 & -62 & -47 & & Lower montane wet forest & -70 & -67 & -58 \\
\hline & Montane wet forest & -98 & -97 & -90 & & Montane rain forest & -91 & -90 & -70 \\
\hline & Subalpine rain paramo & -100 & -100 & -100 & & Tropical wet forest & 653 & 992 & 1277 \\
\hline & Tropical moist forest & 29 & 30 & 24 & & Country & 9 & 9 & 10 \\
\hline
\end{tabular}

species as well as entire biomes, but the question arises what such shifts mean for carbon and more broadly for conservation? On a pragmatic level, baselines for carbon accounting matter a great deal, where maximum carbon credits obtainable are the desired outcome, as in the case for REDD. However over time, should forest shifts occur as the research here illustrates, an important factor for conservation and mitigation activities is that focus should be not necessarily where carbon stocks are the greatest but where there will be a net positive in the projection year from the baseline year. Thus an important focus of policy and conservation efforts should be concentrated on where vulnerable biomes are at most risk, i.e., biomes that shift and/or reduce fall under the vulnerable category.

Other implications of the results are on the quantity and quality of water that flows over and through forests also changes, often for the worse (Cleanet 2013). A considerable contribution that forests make towards the hydrological characteristics of watershed ecosystems is maintaining high water quality. Good forest cover is more effective than any other kind of land cover in keeping the water as sediment free as possible. Natural forest cover, debris and tree roots trap sediments and stop their down-slope movement, as well as provide the most effective barrier to splash-induced soil erosion, stabilize slopes and aid in the prevention of shallow landslides (Calder et al. 2007). Thus all aspect of forest biomass, and changes in it as in the case when forest trend towards drier, less biomass/carbon intensive types as is shown in this study, can thus reduce the amount of water received by rivers and aquifers, and could potentially restrict the availability of freshwater for other purposes.

The results demonstrate that over the studied time, the land type will change, and hence land use and the decisions around the land in question will be affected; this in turn will impact livelihoods, access to resources, and even agricultural practices of that landscape; thus this study can be a starting point for more in-depth work on the suitability of different land types and the subsequent uses and the changes of these uses over time as well as provide information for studies on biodiversity, species richness, and other Environmental Goods and Services (EGS), of different forest ecosystems.

Our study is in line with other papers where ecological models predict that climate change will shift the geographical distribution of tree species (Scholze et al. 2006, Ravindranath et al. 2006) in a number of regions containing in the tropics. Ravindranath et al. (2006) found that $68-77 \%$ of the forest grids in the tropical regions of India are likely to experience shifts in forest types, signifying the vulnerability of tropical forest ecosystems to climate change. There are also indications of a shift towards wetter forest types in some regions and drier forest types in others in the absence of human influence. Cortez \& Stephen (2009) state that under climate change, most of Tanzania's 338000 $\mathrm{km}^{2}$ forests would shift towards drier regimes from subtropical forest and woodland to tropical dry forest and woodland. Jones et 
al. (2009) found that if climate change crosses critical thresholds, the impacts on the tropical rainforest ecosystems are considerable and could become unavoidable and irreversible within human timescales. How a certain ecosystem will respond depends on regional climate change, and on processes such as feedback, $\mathrm{CO}_{2}$ fertilization, and biome sensitivities.

\section{Conclusion}

The topographical landscape of Central America is very complex and diverse, and tropical forests represent a unique barometer for climate change response. An effort is necessary to start/continue considering these ecosystems as key elements for any monitoring of climate change in Central America and other tropical regions. Our results can contribute to some of these aspects, to guide and incorporate into conservation strategies, where an important focus and efforts should be concentrated on, where vulnerable biomes are at most risk. Indications of forest shifts should thus be taken into account when discussing future mitigation and conservation policies. A strong point of our approach is that differences between disaggregated regional and aggregate country levels can be compared. Country level gains are to be viewed with caution as they are diluting potential threats to forest ecosystems and can therefore be misleading. There is considerable uncertainty about future economic, climate and ecological conditions, therefore we must be careful not to interpret these scenarios as the only possible outcomes. A wider framework is needed to take all relevant impacts such as the impact of $\mathrm{CO}_{2}$ fertilization, land use, and economic aspects, all need to be taken into account simultaneously.

Forests are not just about carbon, an appreciation of the many functions, ecological, social and economic that are provided is required. As well as many other EGS, in addition to carbon, forest biomes act as habitats for much of the world's biological diversity, where richness of forest species can manifest in low and high carbon forests, and as regulators of local, regional and global environments. Countries will not be able to put $100 \%$ of their forests under conservation. The demand for forest products will require that some of those forests are used for production. Several governments, including Costa Rica, have passed policies to enhance the protection of forests. Many countries have developed eco-tourism as a means to generate revenue to protect forests (Khatun 2011). This study can play a role and be a starting point of interest to those stakeholders, involved in resource management and development in the land use sector and can provide guidance to policymakers on the impacts of climate change for their nation's forests full stop. The extent and manner in which national and international policies will be interpreted for successful conservation initiatives designed in response to climate and sustainable development goals as to mutually reinforce one another is likely to be important.

\section{Acknowledgments}

The study is further work developed from the concept originally developed under the CLIMBE project ("Climate Change and Biodiversity Loss: The Effects on Ecosystem Services"). We would also like to thanks two anonymous reviewers for their invaluable comments.

\section{References}

Calder I, Hofer T, Vermont, S, Warren P (2007). Towards a new understanding of forests and water. Unasylva, FAO 229: 72.

Chen X, Zhang X, Li B (2003). The possible response of life zones in China under global climate change. Global and Planetary Change 38 . 327-337.

Cleanet (2013). Integrating the carbon and water cycles within an ecosystem esthetic approach to landscapes. Web Site. [online] URL: http://cleanet.org/cln/ccep/integrating_car.html Conde C, Estrada F, Martínez B, Sánchez O, Gay $C$ (2011). Regional climate change scenarios for México. Atmósfera 24 (1): 125-140.

Convention on Biological Diversity (2007). Biodiversity and Climate. Web Site. [online] URL: http://www.cbd.int/doc/bioday/2007/ibd-2007booklet-01-en.pdf

Cortez R, Stephen P (2009). Introductory course on reducing emissions from deforestation and forest degradation and the role of conservation, sustainable management of forests, and enhancement of forest carbon stocks (REDD+): a participant resource manual. The Nature Conservancy, Conservation International, Deutsche Gesellschaft für Technische Zusammenarbeit (GTZ), Rainforest Alliance, and World Wildlife Fund, Inc.

DeClerck FAJ , Chazdon R, Holl KD, Milder JC, Finegan B, Martinez-Salinas A, Imbach P, Canet L, Ramos Z (2010). Biodiversity conservation in human-modified landscapes of Central America: past, present and future. Biological Conservation 143: 2301-2313. - doi: 10.1016/j.biocon.2010. 03.026

Dixon RK, Perry JA, Vanderklein EL, Hiol Hiol F (1996). Vulnerability of forest resources to global climate change: case study of Cameroon and Ghana. Climate Research 6: 127-133. - doi: $10.3354 /$ cr006127

Enquist CAF (2002). Predicted regional impacts of climate change on the geographical distribution and diversity of tropical forests in Costa Rica. Journal of Biogeography 29: 519-534. doi: $10.1046 / j .1365-2699.2002 .00695 . x$

FAO (1999). State of the world's forests 1999. United Nations Food and Agriculture Organization, Rome, Italy.

FAO (2010). Global forest resources assessment
2010. United Nations Food and Agriculture Organization, Rome, Italy.

FAO (2011). Towards a new understanding of forests and water. United Nations Food and Agriculture Organization, Rome, Italy. [online] URL: http://www.fao.org/docrep/010/a1598e/ a1598e02.htm

Gibbs HK, Brown S, Niles JO, Foley JA (2007). Monitoring and estimating tropical forest carbon stocks: making REDD a reality. Environmental Research Letters 2(4): 045023 - doi: 10.1088/ 1748-9326/2/4/045023

Hansen J, Russell G, Rind D, Stone P, Lacis A, Lebedeff S, Ruedy R, Travis L (1983). Efficient three-dimensional global models for climate studies: models I and 11. Weather Review 11: 609-662. - doi: 10.1175/1520-0493(1983)111 $<0609:$ ETDGMF $>2.0$. CO;2

Hijmans RJ, Cameron SE, Parra JL, Jones PG, Jarvis A (2005). Very high resolution interpolated climate surfaces for global land areas. International Journal of Climatology 25: 1965-1978. doi: $10.1002 /$ joc. 1276

Holdridge LR (1947). Determination of world plant formations from simple climatic data. Science 105: 367-368. - doi: 10.1126/science. 105.2727.367

Holdridge LR (1967). Life zone ecology. Tropical Science Center, San José, Costa Rica.

Husch B, Kershaw JA, Beers TW (2003). Forest mensuration ( $4^{\text {th }}$ edn). John Wiley and Sons Inc., Hoberken, NJ, USA.

IPCC (2000). Land use, land-use change, and forestry: summary for policymakers. A special report of the intergovernmental panel on climate change. Published for the intergovernmental panel on climate change. [online] URL: http://www.ipcc.ch/pdf/special-reports/spm/srlen.pdf

IPCC (2007). Summary for policymakers. In: "Climate Change 2007: the Physical Science Basis" (Solomon S, Qin D, Manning M, Chen Z, Marquis M, Averyt KB, Tignor M, Miller HL eds). Contribution of Working Group I to the Fourth Assessment Report of the Intergovernmental Panel on Climate Chang. Cambridge University Press, Cambridge, UK and New York, USA.

Jones C, Lowe J, Liddicoat S, Betts R (2009). Committed terrestrial ecosystem changes due to climate change. Nature GeoScience 2: 484-487. doi: 10.1038/ngeo555

Khatun K (2011). Reconciling timber provision with carbon sequestration opportunities in the tropical forests of Central America. Environmental Science and Policy 14: 12. - doi: 10.1016/j.envsci.2011.05.018

Khatun K, Valdes PJ, Knorr W, Chaturvedi RK (2010). Assessing the mitigation potential of forestry activities in a changing climate: a case study for Karnataka. Forest Policy and Economics 12 (4): 277-286. - doi: 10.1016/j.forpol. 2009.12.001

Lugo AE, Brown SL, Dodson R, Smith TS, Shugart HH (1999). The Holdridge life zones of the conterminous United States in relation to 
ecosystem mapping. Journal of Biogeography 26: 1025-1038. - doi: 10.1046/j.1365-2699. 1999.00329.x

Magaña V, Amador JA, Medina S (1999). The midsummer drought over Mexico and Central America. Journal of Climate 12: 1577-1588. doi: $\quad 10.1175 / 1520-0442(1999) 012<1577: T M-$ DOMA $>2.0 . \mathrm{CO} ; 2$

Manabe S, Wetherald RT (1987). Large-scale changes in soil wetness induced by an increase in carbon dioxide. Journal of the Atmospheric Sciences 44: 1211-1235. - doi: 10.1175/15200469(1987)044<1211:LSCOSW>2.0.CO;2

Matarira CH, Mwamuka FC (1996). Vulnerability of Zimbabwe forests to global climate change. Climate Research 6: 135-136. - doi: 10.3354/ cr006135

Munasinghe M, Swart R (1999). An overview of climate change and its links with development, equity and sustainability. [online] URL: http://www.ipcc.ch/pdf/supporting-material/climate-change-and-des 1999.pdf

Murphy PG, Lugo AE (1986). Ecology of tropical dry forest. Annual Review of Ecology and Systematics 17: 67-88. - doi: 10.1146/annurev.es. 17.110186.000435

Post W, Emanuel W, Zinke P, Stangenberger A (1982). Soil carbon pools and world life zones. Nature 298: 156-159. - doi: 10.1038/298156a0

Ravindranath NH, Joshi NV, Sukumar R, Saxena A (2006). Impact of climate change on forests in India. Current Science 90: 3.

Scholze M, Knorr W, Arnell NW, Prentice IC (2006). A climate-change risk analysis for world ecosystems. Proceedings of the National Academy of Sciences USA 103: 13116-13120. doi: 10.1073/pnas.0601816103

Shugart HH (1998). Terrestrial ecosystems in changing environments. Cambridge Studies in Ecology, Cambridge University Press, Cam- bridge, UK, pp. 522 .

Sitch S, Smith B, Prentice IC, Arneth A, Bondeau A, Cramer W, Kaplan JO, Levis S, Lucht W, Sykes MT, Thonicke K, Venevsky S (2003). Evaluation of the terrestrial carbon cycle, future plant geography and climate-carbon cycle feedbacks using five Dynamic Global Vegetation Models (DGVMs). Global Change Biology 14: 2015-2039. - doi: 10.1111/j.1365-2486.2008. 01626.x

Smith T, Leemans R, Shugart H (1992). Sensitivity of terrestrial carbon storage to $\mathrm{CO}_{2}$-induced climate change: comparison of four scenarios based on general circulation models. Climatic Change 21: 367-384. - doi: 10.1007/BF0014 1377

Tosi JA (1996). An ecological model for the prediction of carbon offsets by terrestrial biota. Report no. 17, Tropical Science Center, San Josè, Costa Rica. 